\title{
Genesis, characterization and classification of some soils of semi arid tropical region of Tamil Nadu
}

\author{
Rajeshwar Malavath* and S.Mani ${ }^{1}$ \\ Department of Soil Science and Agricultural Chemistry, College of Agriculture, Professor Jayashankar Telangana \\ State Agricultural University, Rajendranagar, HYDERABAD (TELANGANA) INDIA \\ (Email: rajeshoct31naik@gmail.com)
}

\begin{abstract}
The study was carried out in the three new research stations of TNAU with varied soil types with an objective to characterize and classify the some red, red laterite and black soils in semi arid tropical region of Tamil Nadu in relation to pedogenesis. The red soils were developed on weathered granite-gneiss parent material at gently sloping lands. The red laterite soils were developed on weathered granite-gneiss over laterite parent material at gently sloping lands to moderately steep sloping lands whereas the black soils were formed at nearly level or plain topography on granitic gneiss parent material mixed with calcareous murram. The red soils and red laterite soils are relatively more weathered than black soils. The red and red laterite soil colour varying from dark red to light reddish brown and dark reddish brown to light reddish brown, the black soils colour varying from very dark gray to dark grayish brown under dry and moist conditions, respectively. The soils are shallow $(27 \mathrm{~cm})$ to very deep $(>170 \mathrm{~cm})$. The surface horizons exhibited mostly medium fine granular to weak sub angular blocky structures whereas in subsurface horizons shown medium fine granular to medium strong sub angular blocky structures in red and red laterite soil pedons. The black soil pedons had coarse strong angular blocky structure. The textural class of fine earth fraction was clayey (52.9 to $64.3 \%$ ) in black soils, whereas in red and red laterite soil pedons it was coarse textured gravelly sandy loam and sandy clay loam in the surface horizons and sandy loam, sandy clay loam and sandy clay in sub-surface horizons (54.5 to $73.7 \%$ sand and 16.5 to $40.9 \%$ clay). The silt content in most of the pedons showed an irregular trend with soil depth. Bulk density increased with increasing depth. The moisture retention at field capacity ( $33 \mathrm{kpa})$, permanent wilting point (1500 kpa) and available water capacity were high in black soils. Based on the morphology, physical, physico-chemical and chemical properties, the soils were classified as per USDA soil taxonomy into four orders viz., vertisols, alfisols, entisols and inceptisols.
\end{abstract}

Key Words : Genesis, Characterization, Classification, Red soil, Red laterite, Black soils, Semi arid tropical region

View Point Article : Malavath, Rajeshwar and Mani, S. (2018). Genesis, characterization and classification of some soils of semi arid tropical region of Tamil Nadu. Internat. J. agric. Sci., 14 (1) : 1-20, DOI:10.15740/HAS/IJAS/14.1/1-20.

Article History : Received : 21.06.2017; Revised : 01.11.2017; Accepted : 14.11.2017

\footnotetext{
* Author for correspondence:

${ }^{1}$ Department of Soil Science and Agricultural Chemistry, Agricultural College and Research Institute (T.N.A.U.), COIMBATORE (T.N.) INDIA
} 